\title{
Manufacturing of Miniature Fluidic Modules for Lab-on-a-Chip using UA Photoresin from Flexographic Platemaking Process
}

\author{
Julio Cesar B. Fernandes and Luiz Otávio S. Ferreira* \\ Departamento de Mecânica Computacional, Faculdade de Engenharia Mecânica, \\ Universidade Estadual de Campinas, CP 6122, 13083-970 Campinas-SP, Brazil
}

\begin{abstract}
Uma nova técnica de fabricação de dispositivos fluídicos miniaturizados foi desenvolvida, usando-se uma foto-resina baseada nos oligômeros uretana e acrilato (UA), usados na indústria gráfica para a confecção de clichês de impressoras flexográficas. Foram fabricados módulos de misturadores e reatores fluídicos medindo $10 \times 10 \mathrm{~mm}^{2}$, providos de canais com largura variando de 0,25 a $1,00 \mathrm{~mm}$ por $0,75 \mathrm{~mm}$ de profundidade. Tampas de $4,00 \mathrm{~mm}$ de espessura, contendo orifícios de 1,26 mm de diâmetro para a entrada e saída do fluido, foram usadas para selar os canais empregando-se um filme de foto-resina como adesivo. Interconexões de tubos de aço foram fixadas aos orifícios de entrada e saída do fluido. Todos os módulos fluídicos foram fabricados por fotolitografia, selados por cura no ultravioleta (UV) de uma camada de adesão de UA, empacotados usando a foto-resina, e suportaram, sem vazamentos, uma pressão de ar de $2 \times 10^{5}$ Pascal.
\end{abstract}

A new technique of fabrication of miniaturized fluidic devices was developed using a photoresin based on urethane and acrylate (UA) oligomers used to platemaking for flexographic printers on graphic industry. Fluidic mixers and reactors modules measuring $10 \times 10 \mathrm{~mm}^{2}$ were manufactured, with channels width in the 0.25 to $1.00 \mathrm{~mm}$ range and $0.75 \mathrm{~mm}$ depth. Top covers $4.00 \mathrm{~mm}$ thick, with $1.26 \mathrm{~mm}$ diameter inlet and outlet holes were used to seal the channels. The sealed channel structures were formed using a film of photoresin as adhesive. Interconnections of $1.20 \mathrm{~mm}$ diameter and $10 \mathrm{~mm}$ long steel tubes were fixed into inlet and outlet holes. All fluidic modules were manufactured by photolithography of UA, sealed by ultraviolet cure of an UA adhesion layer, package in an UA container and successfully tested for leakage under $2 \times 10^{5}$ Pascal air pressure.

Keywords: lab-on-a-chip, mini-fluidic devices, modular systems, urethane-acrylate photoresist, flexography

\section{Introduction}

Miniaturized fluidic devices have great applications in chemical process. Mixers, filters and reactors are used to carry out chemical reactions or physical process of mixture and separation that are important in chemical analysis by flow-injection or for synthesis of new substances.

Fluidic systems may be "mini" or "micro". If the channel dimensions are larger than $0.30 \mathrm{~mm}$ width by $0.60 \mathrm{~mm}$ depth, they are called mini-channels, and microchannels when its dimensions are smaller than $0.18 \mathrm{~mm}$ width by $0.25 \mathrm{~mm}$ depth. ${ }^{1} \mathrm{An}$ advantage of mini-channels against micro-channels is that they are less susceptible to blocking due to particles or bubble gas than microchannels.

* e-mail: lotavio@fem.unicamp.br
Two approaches are possible for fluidic systems, integrated and modular systems. The fluidic functions as separation and mixing are together on the same substrate for integrated system and on separated substrates for modular systems. Modular systems present some advantages as flexibility, simple and low cost production for individual modules. ${ }^{2}$

Silicon is cited as most suited material for the construction of microreactors. ${ }^{2}$ It presents high mechanical and thermal stability, but its cost is high. Alternatively, other materials have been studied as metals, glass, ceramics and polymers. ${ }^{3}$

Polymers are a good alternative for the manufacturing of fluidic devices. Many fluidic devices have been produced using the polymer polydimethylsiloxane (PDMS). It has a number of useful properties: transparency from the visible into the near ultraviolet, chemical inertness, mechanical flexibility and durability, moreover low cost and toxicity. ${ }^{4,5}$ 
Molding is the technology most commonly used to fabricate structures from PDMS. Nevertheless, it is interesting to have commercial polymers with similar properties to PDMS that can be photolythographed.

Urethane-acrylate is a photoresin with large use in graphic arts industry. ${ }^{6}$ It has similar properties to PDMS and it is photolythographed with UV radiation between 350 to $430 \mathrm{~nm}$ wavelength range. ${ }^{6}$

Miniature channels can be manufactured by microelectronics or by graphic arts processes. Graphic arts shops are more available than microelectronics foundries and its manufacturing processes have lower cost than microelectronics.

In this work was developed manufacturing process for miniature fluidic systems based on graphics arts technology.

\section{Experimental}

\section{Apparatus}

The UV-lithography was processed on a custom photoexposer machine equipped with a mercury lamp (350$430 \mathrm{~nm}$ wavelenght) point light source and the exposure

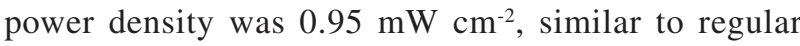
photoexposers from graphic industry. The substrate was the UA photoresin. The fluidic layer was made on by pouring the liquid resin on top of the substrate layer using a mould ( $50 \mathrm{~mm}$ diameter and $1.5 \mathrm{~mm}$ or $4.0 \mathrm{~mm}$ thick) and exposing it to UV up to complete cure. The exposure doses were 415

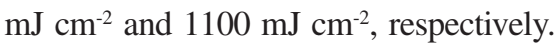

Spray or immersion systems was used on the development step of the exposed substrate using a $0.4 \%$ developer solution in an ultrasonic bath from Unique model 1400.

The photomasks were generated using Intergraph Smartsketch software and were printed on a transparent film at 1200 dpi resolution on a laser printer.

An optical microscope coupled to a color CCD camera from Logitech was used to capture take pictures of devices.

The best development condition of the cured photoresin was determined by measurement of the surface free energy (SFE) of the solid UA. ${ }^{4,7}$ The surface free energy was determined using the free software elaborated by Media and Materials Department of Data Storage Institute, Singapore. In this method, it is necessary to measure the contact angle between the substrate and two different liquids with known surface tension and polarity. The geometric mean method was used for this purpose, and the two liquids used were water and glycerin. The Image Tool free software version 3.00 from University of Texas Health Science Center in San Antonio was used to measure the contact angle.
The liquid surface tension was determined using the weigh of falling drop method. ${ }^{8}$ This method consists on leaving a liquid drop by gravity action and then weighting it on an analytical balance. Surface tension, drop-weight and drop-diameter are interrelated. The drop was formed using an $8.00 \mathrm{~mm}$ diameter glass capillary tube.

The solubility parameter $(\delta)$ of the cured UA photoresin was studied by preparation of a sparsely cross-linked polymer and in the immersion samples in a series of liquids of varying solubility parameter. ${ }^{9}$ The cross-linked photoresin is not dissolve completely, but swells to varying degrees. The amount of swelling is greater in the liquid that has solubility parameter the similar to the photoresin.

The thickness of the substrate and channels layers were measured by a transversal cut of the devices, followed by image acquisition on optical microscope coupled to a color CCD camera. The Image Tool free software was used to thickness measurement.

\section{Reagents and solutions}

Hexane, carbon tetrachloride, toluene, chloroform, acetonitrile, diethyl ether, methyl methacrilate, tetrahydrofurane, diethylene glycol butyl ether, acetone, N-methyl pyrrolidone, $\gamma$-butyrolactone, 2-methyl propanol, npropanol, ethanol, methanol and glycerin were solvents of analytical grade purchased from Merck and Carlo Erba. The aqueous solutions were prepared using $18 \mathrm{M} \Omega$ deionized water. The detergent studied as developer was sodium dodecylbenzenesulfonate. Potassium permanganate, potassium hydroxide and carbodiimide were reagents of analytical grade. The photoresin used in the studies was acquired from Macdermid, trademark FlexLight M050 (density 1.030 and viscosity 1,984 cps).

Preparation of photoresin substrates, mixers and reactors

Samples of photoresin M50-LBS weighting $1.82 \mathrm{~g}$ or $10.00 \mathrm{~g}$ were spread in a $50 \mathrm{~mm}$ diameter and $1.5 \mathrm{~mm}$ or $4.0 \mathrm{~mm}$ of thick mould, respectively. The mould was placed on a flat level and exposed to UV radiation. The resulting substrates were about $0.75 \mathrm{~mm}$ or $4.00 \mathrm{~mm}$ thick. The better exposure dosis to complete polymerization were $415 \mathrm{~mJ}$ $\mathrm{cm}^{-2}$ and $1100 \mathrm{~mJ} \mathrm{~cm}^{-2}$ to $0.75 \mathrm{~mm}$ and $4.00 \mathrm{~mm}$ thick films, respectively.

A second $0.75 \mathrm{~mm}$ layer was spread on top of the 0.75 $\mathrm{mm}$ thick substrate to form the channels layer by photolitography. The mask containing the pattern of mixers or reactors was placed carefully over the liquid photoresin surface so that to adjust without bubbles. Then, it was applied a UV $(\lambda=400 \mathrm{~nm})$ dose of $415 \mathrm{~mJ} \mathrm{~cm}^{-2}$. 


\section{Results and Discussion}

\section{Urethane-acrylate photoresin}

A class of polymers with interesting properties for use as substrate and to manufacture mini-fluidic devices is the urethane, because its presents high tensile strength, elongation great and low hardness. Urethane oligomers are the reaction product of a polyesther or polyether polyols and a diisocyanate. ${ }^{4}$ However, urethane resin is not curable by actinic radiation and then it is necessary to add a reactive monomer to its molecular structure such that it can be used as photoresin. It may be a compound having one acrylate or methacrylate group. The polymerization is initiated using a photoinitiator that allows the start the photopolymerization of the resin on wavelengths above of $330 \mathrm{~nm}$.

The composition of UA photoresin employed in this work is very complex. ${ }^{6}$ Nevertheless, it is very important to know the basic composition of the resin, because it may be used to immobilize biocompounds as enzymes, proteins and nucleic acids for covalent bonding onto surface of fluidic channels producing chemical reactors that it has use in biochemical analysis. The infrared (IR) spectrum shown of Figure 1 informs about the surface structure of this resin. Its complex composition results on many overlapping spectral bands. Generally, it is synthesized by two-step process and after of the synthesis is added a complex mixture of compounds based on methacrylate groups (UV sensitive), antioxidants and photoinitiators (benzophenone) are added, resulting on a photoresin. ${ }^{6}$

Alkene and hydroxyl that absorb at $1628 \mathrm{~cm}^{-1}$ (weak peak) and $3361 \mathrm{~cm}^{-1}$, respectively, are the most interesting families of functional group present in this photoresist. ${ }^{10}$ Alkene can be oxidized to alcohols (hydroxyl groups) by reaction with

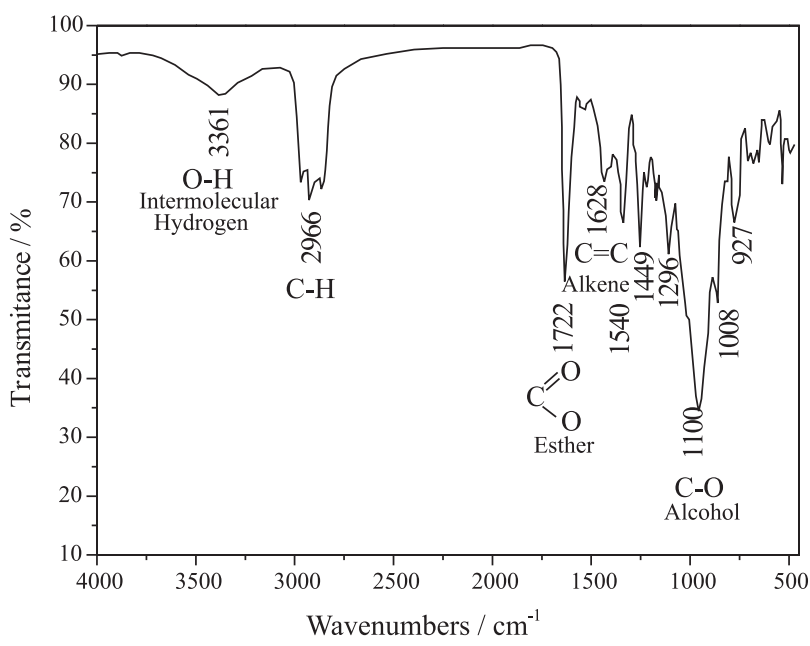

Figure 1. Reflectance Infrared spectrum of the surface of urethane-acrylate photoresin. potassium permanganate. The reaction continues up to form carboxylic acid or ketones compounds, depending if the alcohol produced before is primary or secondary, respectively. These last groups allow covalent bonding with amino groups of the biocompounds, which could be used, for example, for attaching enzymes to channels walls. ${ }^{10}$

The optimal exposure dose to complete polymerization of photoresist layers was studied, as shown in Figure 2. It can be observed that the minimum exposure dose was $415 \mathrm{~mJ} \mathrm{~cm}^{-2}$ and $1100 \mathrm{~mJ} \mathrm{~cm}^{-2}$ to 0.75 and $4.00 \mathrm{~mm}$ thick films, respectively. Below these exposure doses the resin cross-link is not complete.

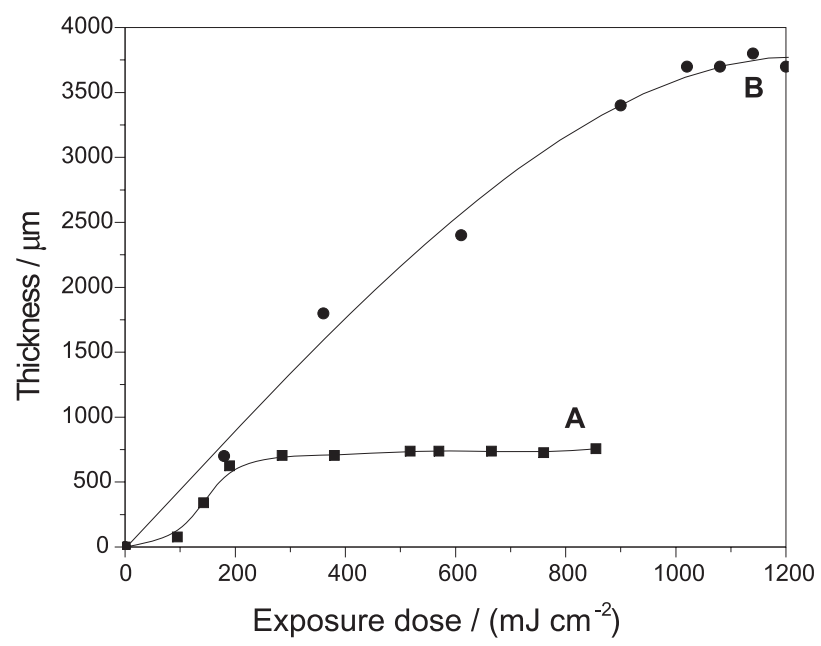

Figure 2. Effect of the exposure dose to complete polymerization of the urethane-acrylate photoresin. Thickness: A, $750 \mu \mathrm{m}$ e B, $4000 \mu \mathrm{m}$.

One interesting property of the UA photoresin to microsystems is that it may be easily developed on aqueous solution of detergents when it has about $10 \%(\mathrm{~m} / \mathrm{m})$ of ethylene oxide in its formulation. ${ }^{6}$ Detergents are more interesting to use as developer than the usual solvents, because their low poisonous action to environment. Moreover, the development step is very important, because it defines a good application of the photoresin. Good development requires that the surface tension of the developer is lower than free energy of the solid surface to allow the wettability of surface. The studies showed that sodium dodecylbenzenesulfonate is the better detergent to be used on development process in the concentration between $0.1 \%$ and $0.5 \%$, where it presents a liquid surface tension about 44 and $28 \mathrm{dyn} \mathrm{cm}^{-1}$, because the surface free energy of the cured UA photoresin is 56 dyn $\mathrm{cm}^{-1}$. For the efficient development of the not cured resist must be made in ultrasonic bath or spray system to improve its mass transport, and on some cases a temperature around $40{ }^{\circ} \mathrm{C}$ is necessary to reduce the surface tension of the detergent solution.

The surface free energy of UA photoresin is two-half time higher than PDMS (24 dyn $\left.\mathrm{cm}^{-1}\right)$. Then, UA photoresin 
presets better wettability in water solutions than PDMS, and decrease pressure drop into mini-channel liquid flow.

The cured UA photoresin presented good chemical resistance to solvents with solubility parameter below 7.4 and above 9.3 Hildebrand with poorly, moderately or strongly hydrogen bonded (Table 1). On the order hand, solvents with solubility parameter between 7.4 and 9.3 Hildebrand can remove the cured UA photoresin by wet etching, destroying the mini-channels. Moreover, the cured UA photoresin has high resistance to acids $(37 \% \mathrm{HCl})$ and concentrated alkalis $\left(40 \% \mathrm{KOH}, 80{ }^{\circ} \mathrm{C}\right)$.

Table 1. Series of tested solvents to chemical resistance of the urethaneacrylate photoresin

\begin{tabular}{|c|c|c|}
\hline Solvent & 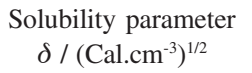 & Swell degree $1 \%$ \\
\hline Hexane & $7.3(\mathrm{p})^{*}$ & 26.7 \\
\hline Carbon tetrachloride & $8.6(\mathrm{p})$ & 247.2 \\
\hline Toluene & $8.9(\mathrm{p})$ & 187.3 \\
\hline Chloroform & $9.3 ;(\mathrm{p})$ & 494.6 \\
\hline Acetonitrile & $11.9(\mathrm{p})$ & 37.5 \\
\hline Diethyl ether & $7.4(\mathrm{~m})$ & 108.4 \\
\hline Methyl methacrilate & $8.8(\mathrm{~m})$ & 176.5 \\
\hline Tetrahydrofurane & $9.1(\mathrm{~m})$ & 244.9 \\
\hline Diethylene glycol butyl ether & $9.5(\mathrm{~m})$ & 29.9 \\
\hline Acetone & $9.9(\mathrm{~m})$ & 87.4 \\
\hline N-methyl pyrrolidone & $11.3(\mathrm{~m})$ & 52.7 \\
\hline$\gamma$-Butyrolactone & $12.6(\mathrm{~m})$ & 19.5 \\
\hline 2-methyl propanol & $11.5(\mathrm{~s})$ & 38.6 \\
\hline n-Propanol & $11.9(\mathrm{~s})$ & 55.4 \\
\hline Ethanol & $12.7(\mathrm{~s})$ & 47.7 \\
\hline Methanol & $14.5(\mathrm{~s})$ & 46.5 \\
\hline Glycerin & $16.5(\mathrm{~s})$ & 3.6 \\
\hline
\end{tabular}

* The letters $\mathrm{p}, \mathrm{m}$ and $\mathrm{s}$ represent the solvents with poorly, moderately and strongly hydrogen bonded, respectively.

\section{Manufacturing fluidic devices with UA photoresin}

Mixers and reactors were designed to fit $10 \times 10 \mathrm{~mm}^{2}$ area modules and manufactured by UV photolytography and curing UA photoresin.

The resolution of manufacturing process of the channels using laser printing transparency was studied manufacturing mixers in different channel widths. It was possible to make channel widths varying from $0.25 \mathrm{~mm}$ to $1.00 \mathrm{~mm}$, for a constant $0.75 \mathrm{~mm}$ depth, using 1200 dpi laser printed transparencies. However, the walls that separate the channels collapsed when their widths was smaller than $0.50 \mathrm{~mm}$ (aspect-ratio > 1.5).

The top cover was also made on $4.00 \mathrm{~mm}$ thick UA film, to support the interconnections. It contains orifices of $1.26 \mathrm{~mm}$ diameter inlet and outlet orifices, compatible with the outer diameter of the interconnections. Conic shape orifices resulted from the diffraction of UV radiation on the mask, with approximately $6.5^{\circ}$ angle, very convenient for fixing the steel tube interconnections into access orifices of top cover.

The interconnection was made from large steel needles, $1.20 \times 1.00 \mathrm{~mm}$ outer and inner diameter, cut to $10 \mathrm{~mm}$ long pieces.

A 3-20 $\mu \mathrm{m}$ thick UA film was used as adhesion layer between the top cover layer and the channels layer. It was noted that if the adhesion layer is thinner than $3 \mu \mathrm{m}$, the adhesion was weak, and if the adhesion layer was thicker than $20 \mu \mathrm{m}$, it flows into the channels, blocking them. The adhesive film of was cured under $25 \mathrm{~J} \mathrm{~cm}^{-2}$ exposure dose. So high dose was necessary because oxygen blocks the photoinitiation step of the UA photoresin polymerization. Thus, a competition between the polymerization and inhibition process occurs in thin films. This inhibition effect is reduced and the adhesion between the top cover and the channels layer is enhanced if the adhesion layer was spreaded under nitrogen atmosphere. The joint formed using this process supported a $2 \times 10^{5} \mathrm{~Pa}$ air pressure.

A package was added to the fluidic module to increase their resistance against shear stress. The devices were placed in a $15 \times 13 \mathrm{~mm}$ and then liquid UA was poured up to cover the device, and then the molded package was exposed to an $1100 \mathrm{~mJ} \mathrm{~cm}^{-2} \mathrm{UV}$ dose. All the manufacturing process steps are summarized in Figure 3.

Several mixers were made with mini-channels width from 0.25 up to $1.00 \mathrm{~mm}$, and tested by injecting the phenolphthalein $\mathrm{pH}$ indicator into one of the input ports and sodium hydroxide into the other. The mixing action was indicated by the formation of a pink color, shown as

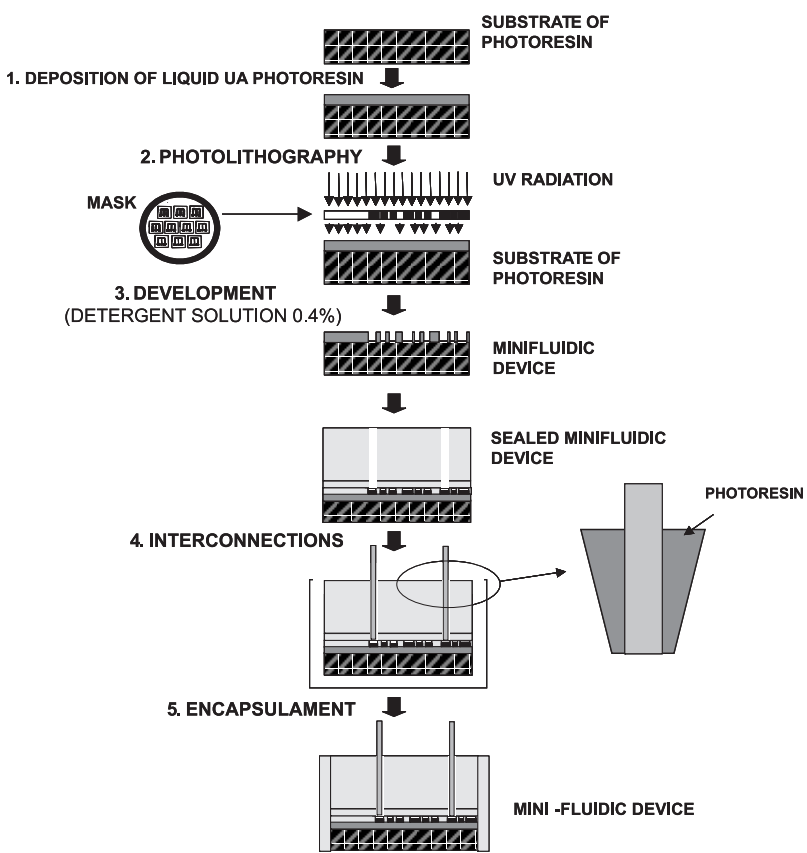

Figure 3. Schematic diagram of the manufacture process of mini-fluidic devices using UA photoresin from flexographic platemaking process. 


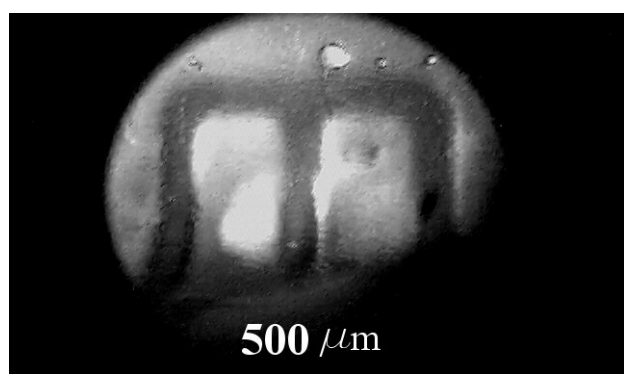

Figure 4. Photography showing the test to leakage for a mixer with 500 $\mu \mathrm{m}$ wide channels.

gray color on Figure 4, where it could be observed that the sealing process was very efficient once that none liquid diffusion occurs by the adhesive joint.

The UA photoresin is highly transparent to visible radiation, and attenuates only $7 \%$ of the transmitted light in the range of wavelengths between 400 up to $850 \mathrm{~nm}$, for $1.00 \mathrm{~mm}$ thick films (Figure 5). It enables the use of the UA photoresin for microlenses or optical wave-guides manufacturing.

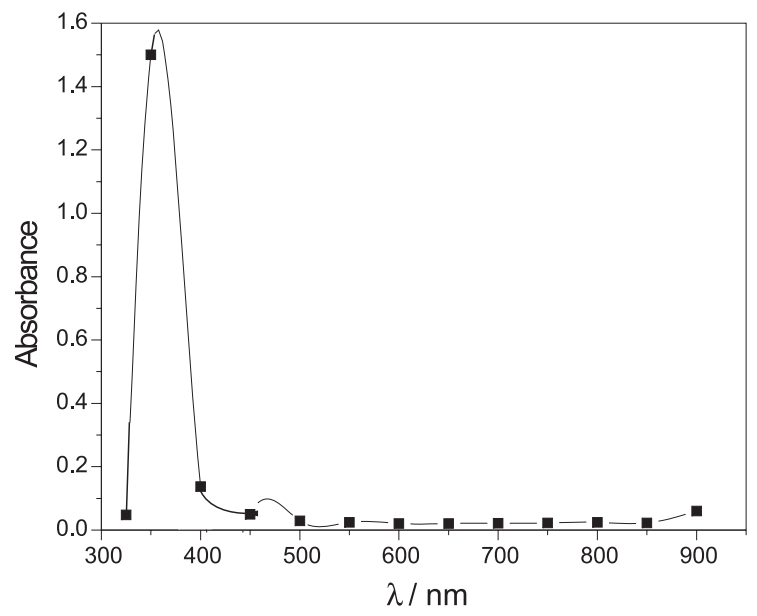

Figure 5. Wavelength scan plot for urethane acrylate photoresin.

On the other hand, UA photoresin has high tacky that allows forming a watertight, non-covalent seal when pressed against itself. This is helpful to temporary sealing of modular fluidic device when demountable is required.

The UA photoresin and its processing technology from graphic arts shown that are useful for manufacturing miniature fluidic devices, presenting the advantages of lower cost an higher availability when compared to microelectronics manufacturing processes.

\section{Conclusions}

The photoresin studied in this work may decrease the fabrication steps of microsystems allowing rapid prototyping or mass production. Its main characteristics are the ecological development in micelar media, high thickness $(4.00 \mathrm{~mm})$ and low cost.
UA photoresin has interesting mechanical, chemical and optical properties as flexibility, easy peeling and semipermanent adhesion due to its high tacky. Its high transparency to visible light allows its use as optical wave-guide.

Finally, due its molecular structure, it is possible to immobilize biocompounds as enzymes, proteins and nucleic acids for covalent bonding onto surface of minichannels allowing the fabrication of bioreactors which they are used in biochemical analysis. An important characteristics of this process based on UA photoresin is that it enables the manufacture of fluidic devices without using other material than UA.

All these characteristics show that this photoresin is a good alternative for microsystem fabrication mainly for the large area devices from mini and microfluidics, when compared to microelectronics manufacturing process and to PDMS based on manufactuting processes, and it allows the start-up of a miniature fluidic systems industry everywhere there is a good graphic arts shop.

\section{Acknowledgment}

The authors thank to FAPESP for financial support process number 01/06262-0.

\section{References}

1. Kovacs, G. T. A; Micromachined Transducers Sourcebook, McGraw-Hill: New York, 1998.

2. Schwesinger, N.; Abstracts of the SPIE-Proceedings 2000, vol. 4177, p. 65.

3. Madou, M. J.; Fundamentals of Microfabrication, CRC Press: Boca Raton, 1997.

4. Skeist, I.; Handbook of Adhesives, $2^{\text {nd }}$ ed., Van Nostrand Reinhold Company: New York, 1977.

5. Whitesides, G. M.; Stroock, A. D.; Phys. Today 2001, 54, 42.

6. Leach, D.; Hockessin, D. E.; US pat. 6,214,522 B1 2001.

7. Zismao, W. A.; Contact Angle, Wettability and Adhesion Advances in Chemistry Series, 43, American Chemical Society: Washington D. C., 1964.

8. Shaw, J. H.; Introduction to Colloid and Surface Chemistry, Butterworth \& CO. Ltd.: Liverpool, 1970.

9. Mark, H.; Bikales, N. M.; Overberger, C. G.; Menges, G.; Encyclopedia of Polymer Science and Engineering, John Wiley \& Sons: New York, 1988, vol. 11.

10. Allinger, N.; Cava, M. P.; De Jongh, D. C.; Johnson, C. R.; Lebel, N. A.; Stevens, C. L.; Química Orgânica, $2^{\text {nd }}$ ed., Guanabara Dois: Rio de Janeiro, 1978.

Received: August 12, 2005

Published on the web: April 28, 2006

FAPESP helped in meeting the publication costs of this article. 